\title{
The Ratification by Greece of the UN Convention on the Law of the Sea
}

\author{
Keywords: Greece; law of the sea; Turkey.
}

\section{INTRODUCTION}

On 21 July 1995, Greece ratified the 1982 UN Convention on the Law of the Sea (hereinafter the 1982 Convention). ${ }^{1}$ The entry into force of a widely accepted and comprehensive law of the sea convention has been a consistent objective of successive Greek administrations since negotiations began over two decades ago. Greece was very active during the Third United Nations Conference on the Law of the Sea (UNCLOS III), voting in favour of the Convention and its Final Act with the intention of ratifying it at a later date. This article discusses the political and substantive context of the Greek ratification of the 1982 Convention by considering its impact upon Greek law of the sea interests and assessing its implications for Greek-Turkish relations in the Aegean Sea.

\section{The Political ConteXt}

Greece ratified the 1982 Convention seven months after its entry into force on 16 November 1994. The debate in Parliament, sitting in plenary session, on the ratification of the Convention ${ }^{2}$ demonstrates the

1. For the text of the Convention, see 21 ILM 1261 (1982). At the same time, Greece ratified the 1994 Agreement on the Implementation of Part XI of the UN Convention on the Law of the Sea, which it had signed on 29 July 1994. The two instruments were approved by Law No. 2321/1995 of 22-23 June 1995, published in Efimeris tis Kiverniseos (Official Gazette) A' 136/1995. As a result, the 1982 Convention entered into force for Greece on 21 August 1995, one month after the deposit of the instrument of ratification, in accordance with Art. 308(2) of the Convention and Art. 3 of Law 2321/1995. The 1994 Agreement is applied provisionally pending its entry into force, according to Art. 7 of the Agreement. See further, A. De Marffy-Mantuano, The Procedural Framerwork of the Agreement Implementing the 1982 United Nations Convention on the Law of the Sea, 89 AJIL 814-824 (1995).

2. See Hellenic Parliament, Praktika tis Voulis (Official Records), Period H', Session B', 31 May 1995.

Leiden Journal of International Law 9: 99-121, 1996.

() 1996 Kluwer Law International 
importance Greece attributes to the entry into force and the universal acceptance of this comprehensive charter of the oceans. All political parties stressed its political significance and the opportunity it offers for Greece to realize its main ocean policy objectives, in particular in expanding its territorial waters to 12 nautical miles (n.m.), a right which, however, Greece is also entitled to exercise under customary law. Although special emphasis was given to the impact of the 1982 Convention on the Greek-Turkish relations, it was argued that the Convention should not be treated only as a reaffirmation of the longstanding Greek position on fundamental national security issues, such as the breadth of the territorial sea and the legal status of islands, but also as an important landmark in the overall development of the law of the sea. There are, of course, conventional rules, such as the right of transit passage or the definition of an archipelagic state, which Greece has opposed, or which are not satisfactorily addressed by the Convention. For example, Greece does not qualify as an archipelagic state under Part IV of the Convention, even though the Greek islands in the Aegean Sea fall within the definition of an archipelago - as provided for by Article 46(b) - and the very notion of an archipelago is drawn from these same islands. Nevertheless, the inclusion of this concept in the 1982 Convention recognizes the geographical, economic, and political entity of groups of islands, such as the Aegean archipelago, and acknowledges their special legal status. The rapporteur of the majority observed that, on balance, the 1982 Convention satisfies substantive Greek interests more than any other international instrument and therefore Greece should become a party.

As mentioned above, the Greek ratification came several months after the adoption of the 1994 Agreement and the entry into force of the Convention. It seems that Greece did not ratify the 1982 Convention at an earlier date because it shared the view of the Commission of the European Communities (EC) at the time, that member states of the European Union could not deposit their ratification or accession instrument individually, but that at least a majority should do so simultaneously with the EC at the appropriate moment. The Commission pointed out that the deposit of instruments of ratification by individual member states, not co-ordinated with the Community, would amount to an infringement of Community law and reserved its right to take any 
appropriate measures. Indeed under Annex IX, Articles 2 and 4, of the Convention, an international organization can only sign or deposit its instrument of informal confirmation or accession to the Convention if the majority of its member states are signatories to it or deposit or have deposited their instruments of ratification or accession. Under Community law, member states cannot commit themselves in matters of exclusive Community competence. If they were to deposit individually their instruments of ratification, they would have to declare that they have transferred certain competences to the Community and that, to that extent, they could not commit themselves. But such a reservation would not be allowed under Article 309 of the 1982 Convention. $^{3}$

This issue was never debated formally, since no member state of the Community then intended to ratify the Convention. The adoption of the 1994 Agreement $^{4}$ removed the obstacle to accession to the Convention by the leading industrialized states and paved the way for a universal participation. The Community expressed its satisfaction with the outcome of these consultations and signed the Agreement on 29 July 1994, with provisional effect as of 16 November $1994 .{ }^{5}$ On 14 October 1994, Germany acceded to the Convention following the ratifications by Italy and Austria on 13 January 1995 and 14 August 1995, respectively.

3. See H. da Fonseca-Wollheim, The European Community and the Law of the Sea Convention, in E. Miles \& T. Treves (Eds.), The Law of the Sea: New Worlds and Discoveries, 26th Law of the Sea Institute Annual Conference (1993). For further discussion, see G. Garzon Clariana, L'Union Européenne et la Convention de 1982 sur le Droit de la Mer, 1995 Revue Belge de Droit International 36-45; and T. Treves, The EEC, the UN and the Law of the Sea, in E.D. Brown \& R.R. Churchill (Eds.), The UN Convention and the Law of the Sea: Impact and Implementation, The Law of the Sea Institute 522 (1987). In the view of Treves, it would seem that only the unanimous authorization by the other member states and the consequent necessary modification of community law would permit these difficulties to be overcome.

4. 1994 Agreement, supra note 1.

5. Council Resolution 94/562/EC, 1994 OJ L 215/9. The provisional application of the Convention by the EC as of 16 November 1994 is confirmed in a letter addressed by the President of the Council to the UN Secretary General of the United Nations. See Garzon Clariana, supra note 3 , at 42 . 


\section{THE SUbSTANTIVE CONTEXT: DECLARATIONS MADE BY GREECE UPON RATIFICATION OF THE CONVENTION}

On ratifying the 1982 Convention, Greece made the following declarations. ${ }^{6}$ Firstly, that Greece affirms all rights and assumes all obligations deriving from the Convention. Greece shall determine how and when it shall exercise those rights, according to its national strategy. This does not mean that Greece renounces its rights in any way. This provision mainly refers to the right of Greece to expand the breadth of its territorial sea to 12 n.m., a right which, as will be discussed below, is unjustifiably contested by Turkey. Secondly, that Greece reiterates its interpretative declaration on the subject of straits, which was made both at the time of the adoption of the Convention and its signature. Thirdly, pursuant to Article 287 of the 1982 Convention, Greece declared that it chooses the International Tribunal for the Law of the Sea for the settlement of disputes concerning the interpretation or the application of the Convention. Fourthly, that as a member of the European Union, it has transferred competence to the Community on a number of matters covered by the Convention. Following the deposit by the Community of its instrument of formal confirmation, Greece will make a special declaration specifying in detail the matters covered by the Convention in respect of which it has transferred competence to the Community, as required by Annex IX, Article 5, of the Convention. Finally, Greece declared that ratification of the Convention in no way implies any recognition on its part of the Former Yugoslav Republic of Macedonia (FYROM). Indeed this recognition, under the provisional name of FYROM, took place by virtue of the Interim Accord which was signed between the two states in New York on 13 September 1995.? The Interim Accord was designated as such because it does not resolve the

6. The original text is in French. See, for the English text, 29 Law of the Sea Bulletin 6 (1995).

7. For the text of the Interim Accord, see 34 ILM 1461 (1995). See also the Memorandum of "Practical Measures" related to the Interim Accord, done at Skopje, 18 October 1995, 34 ILM 146 (1995). 
issue of the name to be used by FYROM. For the same reason, the unusual designation in the Accord Interim of the parties as "the Party of the First/Second Part" was chosen. According to Article 1(1)

upon entry into force of this Interim Accord, the Party of the First Part recognizes the Party of the Second Part as an independent and sovereign State, under the provisional designation set forth in a letter of the Party of the First Part of the date of this Interim Accord, and the parties shall at an early date establish diplomatic relations at an agreed level with the ultimate goal of relations at an ambassadorial level. ${ }^{8}$

The temporary name specified in the afore-mentioned letter is 'Former Yugoslav Republic of Macedonia', pending settlement of the difference that has arisen over the name of the state. ${ }^{9}$

On 20 December 1995, Turkey submitted an 'objection' to the Greek Declaration which states, inter alia, that the signature and ratification of the Convention by Greece and the subsequent declaration in this regard shall neither prejudice nor affect the existing rights and legitimate interests of Turkey with respect to maritime jurisdiction areas in the Aegean and that Turkey fully reserves its rights under international law. Furthermore, Turkey declares that it will not acquiesce in any claim or attempt designed to upset the long-standing status quo in this respect which would deprive Turkey of its existing rights and interests. In its view, any unilateral act that would constitute an abuse of the provisions of the Convention would entail totally unacceptable consequences. $^{10}$

The first question one may pose in this respect is whether Turkey is entitled to sumbit an 'objection' to a declaration made by a contracting party to a treaty, in relation to which it is not even a signatory state. It should be recalled that Turkey was one of the four states which

8. Interim Accord, supra note 7.

9. Pursuant to Art. 23(1), the Interim Accord entered into force on 13 October 1995, i.e. on the 30th day after the date of its signature. The Interim Accord will remain in force until it is replaced by a permanent agreement, provided that after seven years each party shall have the right to withdraw from it with a written statement, which will come into effect 12 months after its presentation to the other party (cf. Art. 23(2)).

10. See Declaration of Turkey, 20 December 1995, to be published in the forthcoming issue of the Law of the Sea Bulletin; the author is indebted to Mr M. Hayashi, Principal Officer, Division for Ocean Affairs and the Law of the Sea, Office of Legal Affairs, United Nations, for providing this information. 
voted against the adoption of the Convention. What is the legal effect, if any, of this 'objection'? Secondly, the Turkish text seems to oscillate between customary and conventional law. On the one hand, it states that it will not acquiesce in any claim designed to 'upset' the long-standing status quo, whilst, on the other hand, it refers to unilateral acts that would constitute an abuse of the Convention, with respect to which, however, it is a third party. As will be discussed below, the Turkish arguments have no legal basis, neither in customary nor in conventional law, nor do they reflect reality.

\section{THE IMPACT OF THE 1982 CONVENTION ON GREEK SUBSTANTIVE LAW OF THE SEA INTERESTS}

\subsection{Provisions with a positive effect}

\subsubsection{Breadth of the territorial sea}

Under Article 3, every state has the right to extend the breadth of the territorial sea to 12 n.m. from the baseline. The twelve-mile limit is firmly established in international law, so that Article 3 should be regarded as embodying a customary rule. As at 16 April 1994, 120 states had claimed 12 n.m. territorial seas. ${ }^{11}$ At present, Greece claims a sixmile territorial sea and a ten-mile territorial sea for the purpose of aviation. ${ }^{12}$ Even though Greece has opted for a six-mile territorial sea, it has repeatedly declared that it reserves its legitimate right under international law to establish a 12-mile territorial sea at a time deemed appropriate. ${ }^{13}$ Law 2321/1995 declared that Greece reserves its right to

11. See 25 Law of the Sea Bulletin 115 (1994).

12. See Decree of 6/18 September 1931: "to define the extent of the territorial waters for the purpose of aviation and the control thereof", Efimeris tis Kiverniseos A' 325/1931; Law No. 230, 17 September 1936: “on the territorial sea of Greece”, Efimeris tis Kiverniseos A' 158/1936; and Code on Public Maritime Law, Decree 187/1973, Efimeris tis Kiverniseos A' 261/1973, Art. 139 of which provides that Greece may alter this limit by a presidential decree, following a proposal by the Council of Ministers. See also United Nations Division for Ocean Affairs and the Law of the Sea, The Law of the Sea: National Legislation on the Territorial Sea, the Right of Innocent Passage and the Contiguous Zone 142 (1995).

13. See Law 2321/1995, supra note 1 . 
expand its territorial waters to 12 n.m. at any time (Article 3). It also stated that for the implementation of this provision as well as other conventional rules concernming, inter alia, the contiguous zone, international straits and the relevant Greek interpretative declaration, the continental shelf, the marine scientific research, and the protection of the marine environment, a presidential decree should be issued. In the view of the writer, this provision was not necessary, as Greece enjoys an inalienable right to expand its territorial sea to $12 \mathrm{n} . \mathrm{m}$., under both conventional and customary international law. Nevertheless, it does illustrate the firm position of Greece in relation to the matter. Finally, it should be noted that during the discussions of this issue in the Greek Parliament, a number of Members of Parliament argued that Greece should use the straight baselines system for drawing the baseline along the Greek coast, which will move the territorial sea limit seaward, as well as establish the 24-mile rule for closing bays, as provided for by both the 1958 Geneva Convention on the Territorial Sea and the Contiguous Zone (TSC) and the 1982 Convention. Presently, Greece uses the normal baseline for measuring the breadth of the territorial sea and the ten-mile rule for the system. To the contrary, Turkey has employed the straight baselines system since $1964 .{ }^{14}$

In a number of cases, either officially through its Prime Ministers and Ministers of Foreign Affairs or unofficially through the press, Turkey has threatened Greece that if it were to establish a 12 n.m. territorial sea, this would be regarded as a casus belli. These threats constitute a violation of Article 2(4) of the UN Charter outlawing the threat as well as the use of force. It should be noted that Turkey itself applies a double standard: it maintains a six-mile territorial sea in the Aegean and a 12-mile territorial sea in the Black Sea and along the Mediterranean coast. ${ }^{15}$ Turkey claims that Greece is not entitled to expand its territorial sea unilaterally since, in its view, the Aegean is a semi-

14. See Act 476 of 15 May 1964, Official Gazette No. 11711, 25 May 1964 (see also UN Doc. ST/LEG/SER.B/15, at 674), Arts. 4 and 5; and Act No. 2674 of 20 May 1982 on the Territorial Sea of the Republic of Turkey, which repealed Act 476/1964, Art. III. Act 2674/1982 does not make a specific reference to straight baselines, but it provides that the Council of Ministers shall determine the baselines from which the breadth of the territorial sea is measured. See United Nations Division for Ocean Affairs and the Law of the Sea, supra note 12 , at 385-386.

15. Act 2674/82, supra note 14; and Decree No. 8/4742 of 29 May 1982. 
enclosed sea and, therefore, such an action would require its prior consent as a bordering state. As argued, the indiscriminate application of the 12-mile rule in semi-enclosed seas constitutes an abuse of right, contravening Article 300 of the 1982 Convention. Finally, Turkey claims that an extension of the Greek territorial sea to 12 n.m. would transform the Aegean Sea into a 'Greek lake' and infringe upon the freedom of navigation.

These arguments have no legal basis and reflect views which were developed by Turkey during the negotiations at UNCLOS III, but which were not accepted and do not form part of the Convention. Neither Article 3 nor the provisions concerning semi-enclosed seas and abuse of rights affect the right of Greece to expand its territorial sea in the Aegean sea unilaterally. The provisions of the 1982 Convention on enclosed and semi-enclosed seas specify clearly the obligations of states bordering such seas; there is no reference to either the extension or the delimitation of the territorial sea (see Section 4.3.2., infra). The 1982 Convention does not exclude enclosed and semi-enclosed seas from its general provisions, nor does it establish an obligation on bordering states to agree on a special regime and special limits. Furthermore, the notion of abuse of right refers to the manner in which a right is exercised and not to the competence of a state to exercise this right. Finally, expansion of the Greek territorial sea will not affect the navigational rights of third states; rights of innocent passage will be respected, as is the case today within the six n.m. territorial sea. Greece, with one of the world's largest merchant fleets, has no incentive to institute measures which might lead to a restriction of its own freedom of navigation. It would, therefore, inevitably be sensitive to these problems.

Special mention should be made of the 1982 Turkish law on the territorial sea which adopts the concept of equity both as a factor in determining the breadth of the territorial $s^{16} a^{16}$ and as a delimitation principle. It appears that Turkey, when it failed to secure the exclusion of the Aegean Sea from the general scheme of the 1982 Convention applicable to the territorial sea, not only refused to sign the Conven-

16. Act $2674 / 82$, supra note 14 , Art. I of which reads: "[t]he Council of Ministers has the right to establish the breadth of the territorial sea, in certain cases, up to a limit exceeding six nautical miles, under reservation to take into account all special characteristics and relevant situations therein, and in conformity with the equity principle". 
tion, but also passed a new domestic law introducing the concept of equity. Nevertheless, the right of Greece to expand its territorial sea to 12 n.m. is based on a customary rule opposable to Turkey. Even in 1956, the Permanent Mission of Turkey to the United Nations, in a Note Verbale dated 2 March 1956, commented on the relevant Draft Articles of the International Law Commission (ILC) that: " $[t]$ he Turkish authorities are of the opinion that the twelve mile limit has already obtained the general practice necessary for its acceptance as a rule of international law". ${ }^{17}$

\subsubsection{Delimitation of the territorial sea}

Article 15 of the 1982 Convention repeats verbatim Article 12 of the 1958 TSC and provides that the delimitation of the territorial sea between states with opposite or adjacent coasts should take place, failing agreement to the contrary, on the basis of the principal of equidistance, unless special circumstances or historic titles call for a different solution. These provisions reflect customary law as, in their vast majority, maritime delimitation agreements employ the principle of equidistance/ median line as the delimitation formula for determining territorial sea boundaries.

During the negotiations at UNCLOS III, Turkey firmly opposed Article 15. Since its proposals for adopting equitable principles and taking the special characteristics of semi-enclosed seas into account were not accepted, it enacted Law 2674/1982 introducing equity as the delimitation principle and replacing Law 467/1964 which provided for the median line. ${ }^{18}$ The adoption of this law would seem to negate the delimitation principles on which existing territorial sea boundaries in

17. See Note Verbale, UN Doc. A/CN.4/99 (1956), reproduced in II YBILC 74 (1956). See also 1973 Protocol Between Turkey and the Soviet Union which provides for a territorial sea delimitation between parties both claiming a 12-mile territorial sea in the Black Sea. See 59 Limits in the Seas (1974); and J.J. Charney \& L.M. Alexander (Eds.), II International Maritime Boundaries 1680-1691 (1993). Only recently has Turkey objected to the 12mile rule. For further discussion, see C. Rozakis, The International Legal Status of the Aegean and the Greek-Turkish Dispute: The Bilateral and International Institutional Issues, in Greek-Turkish Relations: 1923-1987, at 269-492, specifically at 236-252 (1991) (in Greek).

18. See note 14 , supra. 
the Aegean Sea are based. In the north-eastern Aegean, i.e., in the sea area from Evros down to the islands of Samos and Ikaria and the opposite Turkish coast, the territorial sea boundary is based on general customary law and its mutual recognition between the two states, coinciding with the median line. South of these islands, the maritime boundary between the Dodecanese and the Turkish coast, is established conventionally on the same principles by two 1932 Agreements between Italy and Turkey. ${ }^{19}$ Greece succeeded Italy to these Agreements, when Italy ceded the Dodecanese to Greece under the Paris Treaty of Peace With Italy of 10 February 1947 (hereinafter 1947 Paris Peace Treaty). ${ }^{20}$ The median line is also the de facto delimitation line in the Ionian Sea, more specifically in the sea area between Corfu Island and the opposite Albanian coast.

\subsubsection{The contiguous zone and the extenuation of coastal jurisdiction for archaeological purposes}

The 1982 Convention retained the concept of the contiguous zone in Article 33 despite proposals to the contrary which called for its abolition in the light of the establishment of the 12-mile territorial sea and the Exclusive Economic Zone (EEZ). The Convention did not only extend the breadth of the contiguous zone to 24 n.m., but also breathed

19. In this respect, see the Agreement Between the Kingdom of Italy and the Turkish Republic Concerning Sovereignty Over Islets Located Between the Coasts of Anatolia and the Island of Castellorizo, as Well as Over the Islet of Kara-Ada, and on Delimitation of the Territorial Waters Surrounding the Said Territories, 133 LNTS 243-249 (1933). At the same date, there was an exchange of letters whereby the two parties undertook to propose to their respective Governments to proceed immediately with the demarcation of the remaining Italian-Turkish territorial sea boundary, as this was undisputed by the two states, as well as to designate experts to perform this function. In application of the Agreement, a procès-verbal was signed between the two parties at Ankara on 28 December 1932, whereby the remaining territorial sea boundary between the Dodecanese and the Turkish coast was demarcated. Documents on file with the Italian Ministry of Foreign Affairs.

20. In application of well-established principles of succession of states in respect of treaties, which are crystallized in Art. 11 of the Vienna Convention on the Succesion of States in Respect of Treaties (11 ILM 1488 (1978)), these agreements have not ceased to be in force and are binding upon both Greece (as successor state) and Turkey, having in no way been affected by the cession of the Dodecanese to Greece by Italy, by virtue of Art. 14 of the 1947 Paris Treaty of Peace With Italy (49 UNTS 3 (1950)). The latter was approved by Greece by Decree 423 of $21 / 22$ October 1947, Efimeris tis Kiverniseos A' 226/1947. 
new life into it by incorporating it in the scheme of protection provided for underwater cultural property (cf. Article 303). Despite the limiting language of Article 303(2), which confines coastal rights to the "control of traffic" in archaeological and historical objects found on the bed of the contiguous zone, in substance far more extensive rights are recognised. The combination of Article 303(1), which provides for the general duty to protect archaeological objects, and the fiction established by Article 303(2), allows for the expansion of coastal jurisdiction over the 24-mile zone. However, this de facto establishment of an archaeological zone, contiguous to the territorial sea, does not result in the transformation of the general contiguous zone into a full jurisdictional zone. The 24-mile archaeological zone has an independent character which enables its autonomous declaration. ${ }^{21}$ Greece could take advantage of these regulations and extend its jurisdiction, e.g. by including a relevant provision in its new archaeological law which is currently under preparation.

It should be noted that Turkey objects to the expansion of coastal jurisdiction over the contiguous zone. The debate in the Council of Europe on the drafting of a European Convention on the Protection of the Underwater Cultural Heritage is illustrative of this attitude. The 1985 Draft Convention, which was prepared by an $A d$ Hoc Committee of Experts on the Underwater Cultural Heritage, adopts a provision similar to Article 302(2) to define the territorial scope of its application. When the Draft Convention was submitted for approval to the Committee of Ministers, no decision was taken to open it for signature due to Turkey's objection to its territorial scope of application. Turkey proposed either the extension of coastal jurisdiction over the continental shelf, or alternatively, its restriction within the territorial sea boundary. ${ }^{22}$

Unlike the TSC, the 1982 Convention contains no provision on the delimitation of opposite or adjacent contiguous zones. Article 33 fails to refer to the delimitation issue without giving any explanation for this omission. Nor does the examination of the records of the Conference offer any significant help in this respect. It seems that the delimitation

21. See, in this respect, A. Strati, The Protection of the Underwater Cultural Heritage: An Emerging Objective of the Contemporary Law of the Sea 165-171 (1995).

22. Id. 
of opposite or adjacent contiguous zones should take place on the basis of the principle of equidistance, failing agreement to the contrary. This may be justified either as a rule of custom or as an application by analogy of Article 15 dealing with the delimitation of the territorial sea. The 1982 Convention permits its application by providing in its Preamble that " $[\mathrm{m}]$ atters not regulated by this Convention continue to be governed by the rules and principles of general international law". It is true that only a small number of the states that have claimed contiguous zones have made provision for a delimitation formula. However, the majority of those which have done so, establish the principle of equidistance, pending or failing agreement to the contrary, as the delimitation formula of opposite or adjacent continguous zones. ${ }^{23}$

\subsubsection{Adoption of the 200-mile EEZ}

The 1982 Convention provides for a new jurisdictional zone, the 200mile EEZ. Within this zone, the coastal state enjoys extensive rights in relation to natural resources, both living and non-living, of the superjacent waters and of the seabed and its subsoil, as well as jurisdiction with respect to the construction of artificial islands and installations, marine scientific research, and the preservation of the marine environment. Under both the 1982 Convention and customary law, the EEZ and the continental shelf coincide up to the 200-mile limit. ${ }^{24} \mathrm{Nei}-$ ther Greece nor any other Mediterranean state, with the exception of Morroco, has as yet declared an EEZ. ${ }^{25}$ It should be recalled that the

23. See also the Declaration made by Yugoslavia upon ratification of the Convention (Law of the Sea Bulletin, supra note 11, at 20-21), which states, inter alia, that the principles of customary law embodied in Art. 24(3) of the TSC apply to the delimitation of the contiguous zone between the parties to the 1982 Convention (supra note 1). For further discussion, see Strati, supra note 21, at 183-184.

24. See Continental Shelf case (Tunisia/Libyan Arab Jamahiriya), 1982 ICJ Rep. 18, at 74; and Continental Shelf case (Libyan Arab Jamahiriya/Malta), 1985 ICJ Rep. 13, at 33, where the ICJ held that "[i]t is incontestable that the institution of the exclusive economic zone with its rule on entitlement by reason of distance, is shown by the practice of States to have become a part of customary law".

25. However, in the new Law 2288/1995, Efimeris tis Kiverniseos A' 27/1995, relating to the Exploration, Research and Exploitation of Hydrocarbons and Related Issues, which repealed Law 468/1976, reference is made to the EEZ, in case this is proclaimed by Greece. It has been argued that Greece should take the initiative and proclaim an EEZ in the Aegean Sea. The delimitation of an EEZ is as viable a method of resolving the 
conservation and management of fishing resources falls within the exclusive competence of the European Community. ${ }^{26}$ Within the context of the common fisheries policy, 200-mile fisheries zones have been established in the Atlantic and the North Sea on 1 January 1979. When the Commission proposed in July 1990 the declaration by member states of 200-mile fisheries zones in the Mediterranean, ${ }^{27}$ Turkey responded as negatively as it had done in relation to the territorial sea issue: it threatened that if Greece was to establish a fisheries zone in the Aegean Sea, this would be regarded as a casus belli.

\subsubsection{Definition of the continental shelf: adoption of the criterion of distance}

Under Article 76(1) of the 1982 Convention, the continental shelf extends to 200 n.m. from the territorial sea baselines. Where, however, the continental margin extends beyond this 200 -mile limit, the outer edge of the continental margin is taken as marking the outer limit of the continental shelf. Thus, the geological criterion is not taken into consideration if the distance is less than 200 miles. In such areas, title depends solely on the distance from the coast with the geological and geomorphological characteristics being completely immaterial. ${ }^{28}$ Natural prolongation would only provide for the legal basis of title to continental shelf where a geological shelf extends beyond 200 miles from the land.

dispute with Turkey in the Aegean Sea, whilst it will counteract the overexploitation of coastal fish stocks. See T. Kariotis, The Case for a Greek Exclusive Economic Zone in the Aegean Sea, 14 Marine Policy 3-14 (1990). See also A. Syrigos, Territorial Sea: Let's Establish 10 Miles, Economicos Tachidromos, 17 November 1994, at 20 (in Greek).

26. In this respect, see the EC Declaration, supra note 5, at $40-41$, where it is stated that " $[t]$ he Community points out that its member States have transferred competence to it with regard to the conservation and management of fishing resources. Hence in the field of sea fishing it is for the Community to adopt the relevant rules and regulations (which are enforced by the member States) and to enter into external undertakings with third States or competent international organisations".

27. Commission of the European Communities, Outline of a Common Fisheries System in the Mediterranean, Discussion Paper 1136 (1990).

28. See Continental Shelf case (Libya/Malta), supra note 24. Nevertheless, in the view of the Court, the concepts of natural prolongation and distance are not opposed but complementary: see id., para. 34. See also M. Evans, Relevant Circumstances and Maritime Delimitation 51 (1989); and, more recently, Maritime Delimitation Between Greenland and Jan Mayen (Denmark v. Norway), 1993 ICJ Rep. 38. 


\subsubsection{Legal status of islands}

Under the 1982 Convention, all islands in principle can generate all maritime zones, i.e. a territorial sea, a contiguous zone, an EEZ, and a continental shelf. However, "rocks which cannot sustain human habitation or economic life of their own", shall have no EEZ or continental shelf (Article 121(3)). This provision is poorly drafted and creates interpretative problems as the term "rock" is not defined anywhere, nor does the paragraph make it any clearer by referring to "human habitation" and "economic life". Nevertheless, it strengthens the rule that every island which does not qualify as a rock under Article 121(3), generates a continental shelf and an EEZ. In addition, all islands, no matter what their size may be, have a territorial sea and a contiguous zone. There are no more exceptions to the rule, notably not in respect of islands located in enclosed and semi-enclosed seas, as argued by Turkey. These provisions reaffirm the long-standing Greek position that the Greek islands in the Aegean Sea are fully entitled to a continental shelf. In contrast, Turkey claims that the fundamental criterion in defining the continental shelf is natural prolongation and that, as a result, islands are not entitled to a continental shelf, being themselves an extension of the seabed. These arguments contradict established rules of international law. In the North Sea Continental Shelf cases, the Court considered that Article 1 of the 1958 Geneva Convention on the Continental Shelf (CSC), which provides that the continental shelf also refers to the seabed and subsoil of marine areas adjacent to the coast of islands, is a rule of custom. ${ }^{29}$ More recently, in the Jan Mayen case ${ }^{30}$ and in the St. Pierre and Miquelon case, ${ }^{31}$ islands completely separated from the main territory of the metropolitan state faced large mainland territories. The decisions did not question the entitlement of these islands. Rather they placed primary emphasis on the relevant coastal fronts of these islands, despite their substantially shorter length than those of the opposite coasts. As emphasized by the Court, the coast of Jan Mayen, "no less

\footnotetext{
29. See North Sea Continental Shelf cases (Federal Republic of Germany v. Denmark; Federal Republic of Germany $v$. The Netherlands), 1969 ICJ Rep. 4, at 39.

30. Jan Mayen case, supra note 28.

31. Delimitation of the Maritime Areas Between Canada and France, 31 ILM 1149 (1992).
} 
than that of Eastern Greenland, generates potential title to the maritime areas recognised by customary law, i.e. in principle up to a limit of 200 miles from the baselines". ${ }^{32}$

\subsubsection{Protection of the marine environment}

The 1982 Convention has been described as a strong, innovative, and comprehensive environmental treaty, governing over two-thirds of the planet and reflecting a global consensus on the management of the environment. Indeed, the Convention regulates marine pollution from shipping, dumping, seabed activities, and land-based and atmospheric pollution. Its provisions reflect a carefully balanced compromise between coastal states, which attempted to extend their jurisdictional powers ratione loci and ratione materiae, and land-locked states, which were in favour of limiting the legislative discretion of coastal states. As a result, most of the 1982 rules reflect the lowest common denominator acceptable to all parties involved; the most radical innovations of the Convention in this respect concern port-state control and jurisdiction. Greece, which has recently shown increased interest in the protection of the marine environment and has accelerated the pace of its ratifications of environmental conventions, could take advantage of these provisions in order to adopt and enforce more stringent anti-pollution rules and standards.

\subsubsection{Protection of deep seabed cultural property}

The application of the common heritage of mankind principle to the seabed beyond national jurisdiction is a cornerstone of the 1982 Convention. However, these provisions, beyond the fact that they constitute an interesting development of international law, are of no direct concern to Greece. One may specifically mention Article 149 providing for the protection of deep seabed cultural property. Under its provisions, archaeological objects found in the Area are to be "preserved or disposed of" for the "benefit of mankind as a whole", whilst taking into

32. See Jan Mayen case, supra note 28, para. 70. See further J.J. Charney, Progress in International Maritime Boundary Delimitation Law, 88 AJIL 240 (1994). 
consideration the preferential rights of the "State or country of origin, or the State of cultural origin or the State of archaeological and historical origin". The significance of Article 149 is limited to a considerable extent by the failure to establish an international organ to implement the proposed regime. Furthermore, the proposed regime suffers from vagueness and ambiguity. ${ }^{33}$

Greece was very active during the negotiations at UNCLOS III. It raised the archaeological issue and fought for the adoption of protective measures in respect of archaeological objects found on the continental shelf and the Area. However, since the 1982 Convention establishes the 200-mile limit as the minimum breadth of the continental shelf and the Mediterranean is less than 400 miles wide throughout its entire length, the legal regime of the deep seabed has no direct application to the Mediterranean. Greece may, nevertheless, qualify as the state of origin of a wreck or its cargo found on the deep seabed in, for example, the Atlantic Ocean.

\subsection{Provisions with a negative effect}

\subsubsection{Transit passage}

The 1982 Convention envisages a new type of passage, "transit passage", through straits which are used by international navigation between one part of the high seas or an EEZ and another part of the high seas or an EEZ (Article 37). The right of transit passage confers a more serious limitation to coastal sovereignty than the right of innocent passage since it involves both ships and aircraft, whilst submarines may navigate submerged. Under Article 38(2), transit passage is the exercise of the freedom of navigation and overflight for the continuous and expeditious transit of the strait. Transit passage cannot be suspended, not even for security reasons.

As already mentioned, Greece made an Interpretative Declaration on straits upon both signature and ratification of the Convention. In this Declaration, it is stated that where the presence of many islands creates a multiplicity of potential straits, as for example in the Aegean

33. See further Strati, supra note 21, at 296-312. 
Sea, the coastal state may designate routes in which the right of passage is to be exercised. The text of the Interpretative Declaration reads as follows:

Interpretative Declaration on the subject of straits: The present declaration concerns the provisions of Part III 'on straits used for international navigation' and more especially the application in practice of Articles 36, 38, 41 and 42 of the Convention on the Law of the Sea. In areas where there are numerous spread out islands that form a great number of alternative straits which serve in fact one and the same route of international navigation, it is the understanding of Greece that the coastal State concerned has the responsibility to designate the route or routes, in the said alternative straits, through which ships and aircrafts of third countries could pass under transit passage regime, in such a way as on the one hand requirements of international navigation and overflight are satisfied and on the other hand the minimum security requirements of both the ships and aircraft in transit as well as those of the coastal State are fullfilled. ${ }^{34}$

It is highly questionable whether the regime envisaged by the 1982 Convention has acquired the status of a customary rule. ${ }^{35}$

\subsubsection{Optional exception of delimitation disputes from compulsory dispute settlement}

As pointed out, the 1982 Convention represents for the majority of the community of nations a commitment to the rule of law and a basis for the conduct of affairs amongst them. Far more significant are substan-

34. For the text of the Declaration, see 29 Law of the Sea Bulletin 6-7, at 7 (1995). To date, the only state which has protested to this declaration is Turkey. However, as pointed out, this 'objection' lacks legal effect.

35. The customary law position on this question is the weakest and the most difficult to defend. See, e.g., Restatement (Third) of Foreign Relations Law of the United States, Part $\mathrm{V}$ (The Law of the Sea), which declares that the provisions of the Convention dealing with transit passage are also customary law, but offers no independent reference to or an assessment of the basis in state practice that it appears to believe to exist. See W. Burke, Remarks, in The Law of the Sea: Customary Norms and Conventional Rules, 81 American Society of International Law Proceedings 75-84 (1987). In contrast, see R. Wainright, Navigation Through Three Straits in the Middle East: Effects on the United States of Being a Non-Party to the 1982 Convention on the Law of the Sea, 18 Case Western Reserve Journal of International Law 361-414 (1986); K. Burke \& D. DeLeo, Innocent Passage and Transit Passage in the United Nations Convention on the Law of the Sea, 9 Yale Journal of World Public Order 389-408 (1983); and S.N. Nandan \& D.H. Anderson, Straits Used for International Navigation: A Commentary on Part III of the United Nations Convention on the Law of the Sea, 60 BYIL 159-204 (1989). 
tive and dispute settlement provisions, which establish procedures to help restrain unreasonable claims and which contribute to a stable legal order. Nevertheless, it is regrettable that sea-boundary delimitation can be excluded from the general scheme of dispute settlement by a declaration made upon signature, ratification, or accession. In such cases, the state(s) concerned must nonetheless accept compulsory conciliation. Disputants are obliged to negotiate an agreement on the basis of the conciliation commission's report; however, if they do not do so, they must agree upon some other procedure for settling the dispute. ${ }^{36}$

The position of Greece has been invariably in favour of submitting legal disputes (including maritime delimitation disputes) to the ICJ, whilst Turkey opposes any general system of compulsory jurisdiction in matters of the law of the sea. The attitude of Turkey was demonstrated also by its abstention from the proceedings in the Aegean Sea Continental Shelf case. $^{37}$

\subsection{Provisions with a neutral effect}

\subsubsection{Delimitation of the EEZ and the continental shelf}

The question of the delimitation of the continental shelf between states with opposite or adjacent coasts was one of the most controversial issues during UNCLOS III. Two were the main contesting groups, the 'equity group' supported by Turkey and the 'equidistance/median line group' supported by Greece. The question of delimitation was resolved with a compromise proposal which neither mentions equidistance nor equity. This compromise formula was presented by the President of the Conference, Mr T. Koh, on 27 August 1971. It is noteworthy that in March 1982, during the 11th and final session in New York, the representative of Turkey argued that

with regard to Articles 74 and 83 , Turkey was not bound by any convention or agreement and no international custom in the matter could be

36. See Art. 298(1.a) of the 1982 Convention, supra note 1.

37. See Aegean Sea Continental Shelf case (Greece v. Turkey), Order, 1976 ICJ Rep. 3. The Court found that it had no jurisdiction to entertain the Greek application for reasons not related to the substance of the case. 
invoked as binding international rules in respect of Turkey. My country's view is that those issues in such seas could only be settled by agreements reached directly between the parties concerned on the basis of equity, and it therefore maintains its right to formulate reservations also on Articles 74 and 83. It was evident that islands situated in such semi-enclosed seas presented problems for the same reasons. Article 121 was unacceptable in its present form and my country maintains its right to reserve its position on that too. ${ }^{38}$

The identical - but vague - language of Articles 74 and 83 provides that delimitation shall be effected by agreement, on the basis of international law, as referred to in Article 38 of the Statute of the International Court of Justice (ICJ) in order to achieve an equitable solution. Whatever solution to the delimitation problem of the continental shelf should, therefore, be based on international law. In fact, achieving an equitable solution within the context of Articles 74 and 83 denotes just the object at which the efforts for the delimitation should aim, whilst equitable principles have always been envisaged and put forward by their supporters as a means, an almost autonomous principle, which has to be applied to reach a just solution. Most importantly, the reference to Article 38 of the ICJ Statute indicates that the Court may rule on a dispute ex aequo et bono only when the parties agree to it. This in a way excludes an eventual application of equitable principles based on purely subjective appreciations and not on the rule of law, since any subjective application would amount to an ex aequo et bono decision. Equity functions infra legem and does not set aside rules of international law, i.e. that islands are entitled to a continental shelf, but specifies delimitation to the geographical circumstances of each case. There is no question of distributive justice or refashioning of geography. Thus

the justice of which equity is an emanation, is not abstract justice, but justice according to the rule of law; which is to say that its application should display consistency and a degree of predictability; even though it looks with particularity to the peculiar circumstances of an instant case, it also looks beyond it to principles of more general application. ${ }^{39}$

Recent jurisprudence of the ICJ reveals a shift towards the principle of

38. See Kariotis, supra note 25 , at 5-6.

39. See Continental Shelf case (Libya/Malta), supra note 24, paras. 45-46; see also North Sea Continental Shelf cases, supra note 29, paras. 85-88; and Rozakis, supra note 17, at 327. 
equidistance. As argued,

in Jan Mayen, the Court took equidistance out of the cellar and gave some recognition to its logic and importance in maritime boundary delimitations of the continental shelf as well as those of exclusive fisheries and economic zones, and of single maritime boundaries [...]. ${ }^{40}$

It seems that equidistance will be adopted as the starting point for a delimitation involving opposite states irrespective of whether the delimitation is conducted on the basis of customary law, Article 6 of the Geneva Convention on the Continental Shelf, or Articles 74 or 83 of the 1982 Convention. ${ }^{41}$ As illustrated by state practice, equidistance easily exceeds all other methods of maritime boundary delimitation in frequency of use.

These recent developments support the Greek position in the Aegean continental shelf dispute. Greece claims that delimitation should take place on the basis of the principle of equidistance/median line, measured from the Greek islands and the opposite Turkish coast, whilst Turkey alleges that the medial line should be drawn between the two mainlands ignoring islands. In the view of Turkey, delimitation should be effected on the basis of equitable principles. Turkey bases its claim on the fact that the Greek islands are on the natural prolongation of the Anatolian peninsula and, as a result, are not entitled to any continental shelf. In a second line of argument, Turkey alleges that the proximity of the Greek islands to its coast, and indeed the whole Aegean Sea, constitute special circumstances so as to displace the principle of equidistance, measured from opposite coasts, including islands. Finally, Turkey claims that the Aegean is a semi-enclosed sea which requires special limits and rules of delimitation. As already pointed out, these arguments are not

40. Charney, supra note 32, at 245.

41. M.M. Evans, Less Than an Ocean Apart: The St. Pierre and Miquelon and Jan Mayen Islands and the Delimitation of Maritime Zones, 43 ICLQ 678-696 (1994). In the Jan Mayen case, the Court accepted the view that "the equidistance/special circumstances" rule under the TSC produces the same result as "the equitable principles/relevant circumstances" rule used in general international law in the case of opposite coasts. See Jan Mayen case, supra note 28, at 62-63. However, this was not used as a means to undermine equidistance, but to underscore its crucial role in the process of delimitation both in conventional and customary law. But see, R.R. Churchill, The Greenland-Jan Mayen Case and Its Significance for the International Law of Maritime Boundary Delimitation, 9 The International Journal of Marine and Coastal Law 1-29, at 14-15 (1994). See, for the 1982 Convention, note 1 , supra. 
legally founded, as both under conventional and customary international law, islands are fully entitled to a continental shelf. ${ }^{42}$

\subsubsection{Introduction of the concept of enclosed and semi-enclosed seas}

The Convention introduces in Part IX the concept of enclosed and semi-enclosed seas. Under Article 123, states bordering such seas should co-operate with each other in the exercise of their rights and the performance of their duties. Such co-operation is exclusively specified in matters related to the management and conservation of living resources, the protection of the environment, scientific research, and co-operation with other states. The language used ("States [...] should co-operate"), does not impose a legal obligation, neither does the Convention establish special delimitation rules as proposed by Turkey during the negotiations. ${ }^{43}$ Turkey also attempted to relate Article 123 to Article 300 dealing with abuse of rights. As none of these proposals were incorporated into Part IX of the Convention, there is a strong a contrario argument that the notion of semi-enclosed seas is not related at all to sea-boundaries.

4.3.3. The right of land-locked states to access to and from the sea and the freedom of transit

The 1982 Convention recognizes in Article 125 the right of access of land-locked states to and from the sea for the purpose of exercising the

42. See also the Anglo-French Continental Shelf Arbitration (18 ILM 397 (1979)), where the Court held that the adopted "enclave" solution was equitable for an isolated group of islands on the wrong side of the median line, but would be inappropriate for a "case where numerous islands stretch out one after another long distances from the mainland", a situation like the Aegean, where the islands are numerous, connected geographically with the Greek mainland and dominate the whole sea area. For a discussion on the Greek-Turkish continental shelf dispute, see D.W. Bowett, The Legal Regime of Islands in International Law 249-281 (1979); C. Dipla, The Greek-Turkish Dispute Over the Continental Shelf of the Aegean: Alternatives and Proposals (1992); Kariotis, supra note 25; M. Stavrinos, The Problem of the Continental Shelf in the Aegean (1992) (in Greek); and Rozakis, supra note 17.

43. UN Doc. C.2/Informal Meeting/18Rev.1 (1978). It is notable that the ICJ in its two judgments concerning the Mediterranean overlooked such arguments. See Continental Shelf case (Tunisia/Libya) and Continental Shelf case (Libya/Malta), supra note 24. See further Dipla, supra note 42 , at 81-82. 
rights provided for in the Convention. To this end, land-locked states shall enjoy freedom of transit through the territory of transit states. This right, however, is considerably qualified. Firstly, its exercise depends on the terms and modalities agreed between transit states and land-locked states through bilateral, sub-regional, or regional agreements. In other words, for the enforcement of this right an agreement between the two states will always be required ('imperfect right'). Secondly, transit states in the exercise of their full sovereignty over their territory shall have the right to take all measures necessary to ensure that the rights and facilities provided for land-locked states shall in no way infringe upon their legitimate interests. Article 125 is a pactum de contrabendo requiring states parties to the 1982 Convention to enter into negotiations in good faith to conclude an agreement. However, it does not indicate the legal consequences in the event that no agreement is reached. It would seem that transit states are not obliged to provide access in the absence of an implementing treaty since none of the proposals to the contrary submitted during UNCLOS III were incorporated in Part $\mathrm{X}^{44}$ In such cases, the Convention's provisions on settlement of disputes may be invoked. It should be noted, however, that this type of disputes falls within the limitations to the compulsory settlement of disputes provided for by the Convention as they concern the exercise by a coastal state of its sovereign rights or jurisdiction (Article 297(1)). As a result, the general provisions of Part XV on dispute settlement will be applicable.

FYROM is the only land-locked neighbouring state of Greece. The afore-mentioned Interim Accord between the two states takes into account the fact that FYROM is a land-locked state and makes reference to the relevant provisions of the 1982 Convention. ${ }^{45}$ FYROM became a party to the Convention on 19 August 1994 by succession to the ratification by Yugoslavia. Any future agreement in this area should be in conformity with community law and take into account the obliga-

44. See S. Vascianne, Land-locked and Geographically Disadvantaged States in the International Law of the Sea 188 (1990); P. Tavernier, Les Nouveaux États Sans Littoral d'Europe et d'Asie et l'Acces a la Mer, 97 RGDIP 727-744 (1993); and I. Wani, An Evaluation of the Convention on the Law of the Sea From the Perspective of the Land-Locked States, 22 VJIL 627-665 (1982).

45. See Art. 13 of the 1982 Convention, supra note 1. 
tions of Greece deriving from its membership to the European Union. It is notable that the EC, in its Declaration upon signature of the Convention stated that "with regard to Part X, the Community has certain powers as its purpose is to bring about an economic union, based on a customs union". ${ }^{46}$

\section{CONCLUSION}

It is obvious from the above analysis that on balance, the positive factors well outweigh the negative ones. The rules on transit passage, in particular the right of overflight, appear to be the only real negative provisions of the 1982 Convention in terms of Greek interests. Provisions on delimitation of the EEZ and the continental shelf, land-locked states, and enclosed and semi-enclosed seas may be classified as neutral in the sense that they neither benefit nor prejudice Greek interests. In this article, only those rules which are of direct concern to Greece and affect significantly its interests were examined. However, the Convention accommodates a great variety of political, economic, social, and strategic interests. For example, the 1982 Convention regulates maritime issues, such as navigational rights, exercise of flag state jurisdiction on manning and equipment of vessels, and the new institution of the prompt release of vessels in a manner which is not prejudicial to Greek commercial shipping interests. It is hoped that the universal participation and application of the Convention will provide a basis for avoiding conflicts and establishing the rule of law in the wider area of the Mediterranean and the Aegean Sea in particular.

46. See Art. 113 of the EC Treaty. 